\title{
Fisiologia Reprodutiva e Reprodução em Cativeiro da Onça Pintada (Panthera onca): Revisão de Literatura
}

\author{
Bruno Pedon Nunes ${ }^{1}$, Darlan Schmitt ${ }^{1}$, Helen Cristina Nogueira Motta ${ }^{1}$, Tatiane \\ Bertonceli $^{1}$
}

${ }^{1}$ Universidade Estadual do Centro Oeste, Campus CEDETEG, Departamento de Medicina Veterinária. Guarapuava, Paraná. [helencris_motta@hotmail.com]

ISSUE DOI: $10.3738 / 1982.2278 .1133$

A Onça Pintada (Panthera onca) é o maior felídeo das Américas, sendo encontrada desde o México até a Argentina. Apresenta um corpo robusto e musculoso, com tamanho médio de 132 $\mathrm{cm}$, e membros relativamente menores que outros animais desse gênero. A principal característica é o corpo todo coberto por pintas negras e a coloração varia entre amarelo-claro e castanho-ocre (Oliveira e Cassaro, 2005). Os animais podem desenvolver um método de sazonalidade, que visa uma melhor sobrevivência e adaptação dos filhotes. Isso ocorre porque concentrando os nascimentos numa época especifica do ano, geralmente entre o fim do verão e inicio da primavera, há uma melhor disponibilidade de alimentos e temperaturas mais amenas. As condições de sazonalidade variam em função da genética e do ambiente. Nos animais em vida livre, os principais fatores de influencia na sazonalidade são o fotoperíodo e de disponibilidade de alimentos (MOREIRA, 2001). Mas os animais em cativeiros o distresse afeta a saúde dos animais em cativeiro de diversas maneiras, mas, sem dúvida, a mais evidente é o comprometimento das funções reprodutivas como demosntrado por Carlstead e Shepherdson em 1994. Ele exerce uma influência direta na fisiologia sexual, alterando a produção de hormônios reprodutivos como o estradiol, a progesterona e a testosterona. A resposta fisiológica ao estresse envolve um mecanismo de ativação do eixo hipotálamo-pituitária-adrenal (HPA) quando o animal se encontra em uma situação de ameaça. Essa ativação estimula a liberação do hormônio liberador de corticotrofina (CRH) pelo hipotálamo, que incita a liberação do hormônio adrenocorticotrópico (ACTH) pela hipófise e de glicocorticoides pelo córtex da adrenal (Moberg, 2000). Por conta disso é necessário o reconhecimento desse estresse e alivio do mesmo. Por conta disso, torna-se necessário reconhecer os fatores desencadeantes de estresse e modificar o manejo dos animais visando à redução do problema, e com isso, essa espécie obter maior sucesso reprodutivo em cativeiro.

Palavras- chave: Panthera onça, reprodução, cativeiro, fisiologia. 